\title{
Pain prevalence in nine- to 13 -year-old school children
}

\author{
Adam van Dijk MSc${ }^{1}$, Patricia A McGrath $\mathrm{PhD}^{2,3}$, William Pickett PhD ${ }^{1}$, Elizabeth G VanDenKerkhof $\mathrm{RN}_{\mathrm{DrPH}}^{1,4}$
}

A van Dijk, PA McGrath, W Pickett, EG VanDenKerkhof. Pain prevalence in nine- to 13-year-old school children. Pain Res Manage 2006;11(4):234-240.

BACKGROUND: Despite significant progress in the epidemiology of chronic pain in adults, major gaps remain in our understanding of the epidemiology of chronic pain in children. In particular, the incidence, prevalence and sensory characteristics of many types of pain in Canadian children are unknown.

OBJECTIVES: A study to obtain the lifetime and point prevalence of common acute pains, recurrent pain syndromes and chronic pains was conducted in a cohort of 495 school children, nine to 13 years of age, in eastern Ontario.

METHODS: Children reported their pain experiences and described the intensity, affect and duration of the pains experienced over the previous month by completing the Pain Experience Interview Short Form.

RESULTS: The majority of children (96\%) experienced some acute pain over the previous month, with headache $(78 \%)$ being most frequently reported. Lifetime prevalence for certain acute pains differed significantly by sex $(\mathrm{P}<0.05)$. Fifty-seven per cent of children reported experiencing at least one recurrent pain, while $6 \%$ were identified as having had or currently having chronic pain.

DISCUSSION: The prevalence of acute pain in this Canadian cohort is consistent with international estimates of acute pain experiences (ie, headache) and recurrent pain problems (ie, recurring headache, abdominal pain and growing pains). However, $6 \%$ of children reported chronic pain. The self-completed Pain Experience Interview - Short Form provides a feasible administration technique for obtaining population estimates of childhood pain, and for conducting longitudinal studies to identify risk and prognostic factors for chronic pain.

Key Words: Children; Chronic pain; Cross-sectional study; Epidemiological study; Pain experience interview; Pain prevalence; Recurrent pain

\section{La prévalence de la douleur chez les enfants de neuf à 13 ans en milieu scolaire}

HISTORIQUE : Malgré des progrès importants dans l'épidémiologie de la douleur chronique chez les adultes, il reste des lacunes majeures dans notre compréhension de l'épidémiologie de la douleur chronique chez les enfants. Notamment, on ne sait rien de l'incidence, de la prévalence et des caractéristiques sensorielles de nombreux types de douleur chez les enfants canadiens.

OBJECTIFS : Une étude pour obtenir la prévalence à vie et la prévalence ponctuelle de douleurs aiguës courantes, de syndromes de douleurs récurrentes et de douleurs chroniques menée auprès d'une cohorte de 495 enfants de neuf à 13 ans en milieu scolaire de l'est de l'Ontario.

MÉTHODOLOGIE : Les enfants ont expliqué leurs expériences de la douleur et en ont décrit l'intensité, l'effet et la durée au cours du mois précédent à l'aide du formulaire court d'entrevue sur l'expérience de la douleur.

RÉSULTATS : La majorité des enfants (96\%) ont connu une douleur chronique au cours du mois précédent, les céphalées (78 \%) étant la plus courante. La prévalence d'une vie de certaines douleurs aiguës différait considérablement selon le sexe $(\mathrm{P}<0,05)$. Cinquante-sept pour cent des enfants ont déclaré avoir ressenti au moins une douleur récurrente, tandis que $6 \%$ d'entre eux ont été dépistés comme souffrant ou ayant souffert de douleurs chroniques.

DISCUSSION : La prévalence de douleur aiguë au sein de cette cohorte canadienne concorde avec les estimations internationales des expériences de la douleur (c'est-à-dire céphalées) et les troubles récurrents de douleur (céphalées, douleurs abdominales et douleurs de croissance), Cependant, $6 \%$ des enfants déclaraient des douleurs chroniques. Le formulaire court autoévalué d'entrevue sur l'expérience de la douleur est une technique d'administration praticable pour obtenir une estimation de la douleur infantile au sein de la population et pour mener des études longitudinales afin de repérer les facteurs pronostiques et les facteurs de risque de la douleur chronique.
C

Thildren experience a diverse array of acute pains (generally related to minor tissue injury or inflammation), recurrent pain syndromes (such as repeated episodes of headache or abdominal pain that affects otherwise healthy children) or chronic pains (prolonged pain that lasts typically for a minimum of three months) (1).

Despite significant progress on the epidemiology of chronic pain in adults, significant gaps remain in our understanding of the epidemiology of chronic pain in children, especially information on the incidence and prevalence of most types of chronic pain, the natural history for nondisease-related pain, risk factors for developing chronic pain, and the burden of illness for families and health care systems $(2,3)$. Populationbased estimates of chronic nonspecific pain (eg, pain in knee, low back and dysmenorrhea) vary from $3.9 \%$ to $48 \%$ (2) depending on sampling strategy, pain definitions, age and sex of study populations, survey methodology and country of origin. Most epidemiological studies on chronic pain in children have focused on nonspecific pain and on recurrent pain syndromes $(2,3)$. While increasing attention is focusing on

${ }^{1}$ Department of Community Health and Epidemiology, Queen's University, Kingston; ${ }^{2}$ Divisional Center of Pain Management and Pain Research, Hospital for Sick Children; ${ }^{3}$ Department of Anesthesiology, University of Toronto, Toronto; ${ }^{4}$ Department of Anesthesiology, and School of

Nursing, Queen's University, Kingston, Ontario

Correspondence: Dr Elizabeth VanDenKerkhof, Queen's University, Kingston General Hospital, 76 Stuart Street, Kingston, Ontario K7L 2V7.

Telephone 613-549-6666 ext 3964, fax 613-548-1375, e-mail ev5@post.queensu.ca 
documenting the prevalence of chronic pain in various countries, there is a paucity of North American data. Moreover, few studies have explicitly evaluated the sensory characteristics of pain in children (3).

We need to obtain accurate age- and sex-stratified estimates of the prevalence and sensory characteristics of pain in Canadian children, and identify potential risks and prognostic factors for chronic pain in childhood. During the first stage in our epidemiological program, we surveyed a cohort of nine- to 13-year-old school children using a shortened version of the Pain Experience Interview.

The Pain Experience Interview is an intervieweradministered screening questionnaire validated for children with different types of acute, recurrent and chronic pain in a clinical setting (4). The interview also provides information on the intensity, affect, duration and frequency of pain experiences in children. Although validated as an intervieweradministered questionnaire, it was intended for eventual use as a population-based screening survey where probable pain conditions were identified in a preliminary self-report screening procedure. Children were further evaluated for objective diagnostic classification. The present study is the first to use this instrument in a broader nonclinical population to determine prevalence and sensory characteristics of pain and to assess the feasibility of the methodology for wider population-based, longitudinal studies on pain in children in Canada.

The primary objective of the present study was to determine self-reported lifetime and point prevalence of acute and chronic pain in a cohort of school children nine to 13 years of age. We focused on this age group because it is a critical time period in a child's development when certain chronic pain problems may first appear and may differentially affect girls and pubertal adolescents. The secondary objective was to characterize pain based on the intensity, affect, frequency and duration for the total sample and by sex.

\section{METHODS}

\section{Design}

A cross-sectional questionnaire was conducted in the spring of 2005 in a cohort of school children nine to 13 years of age, to obtain lifetime and point prevalence estimates of certain types of acute, recurrent and chronic pain. A convenience sample of children attending 20 of the 95 elementary schools in the Kingston and Belleville areas of eastern Ontario completed the selfadministered Pain Experience Interview - Short Form. A child's urban or rural status was classified by using the respective schools' postal code. Children attending a school where the second number of the postal code was a zero were categorized as living in a rural setting. Ethical approval was obtained from the Health Sciences Research Ethics Board at Queen's University (Kingston, Ontario), the Limestone District School Board (Kingston, Ontario), and the Algonquin and Lakeshore Catholic District School Board (Napanee, Ontario).

\section{Participants}

All children in grades 5 and 6 in participating schools were approached for inclusion in the study. This cohort was selected for biological and administrative reasons. From a biological perspective, the study needed to capture students in the pre- and early pubescent stages, due to the potential impact of hormones on pain reporting. Administratively, this cohort was accessible through the elementary school system, making questionnaire administration more manageable.

\section{Procedure}

Principals of 48 schools were contacted, of which 20 (42\%) agreed to participate. Parental consent forms were sent home with all students in grades 5 and 6 . One of the authors had intended to visit each school and explain the survey to consenting students but due to an ongoing labour dispute in the local school system, this was not feasible. Thus, for $54 \%$ of the participants, packages containing the consent form, the information letter and the questionnaire were sent home with the student. If parental consent was provided, the child completed the questionnaire at home. All completed and uncompleted packages were requested to be returned to the school, regardless of consent status.

\section{Questionnaire}

The Pain Experience Interview (4) was revised for selfadministration after the removal of redundant items from the original data set (ie, types of acute pain with comparable prevalence across sex, health groups and throughout the range of fiveto 17-year-old children in the original study), while retaining items that had discriminant validity for differentiating between children based on sex, age and health status. The resulting Pain Experience Interview - Short Form included 13 of the original 56 acute pain items (Table 1 ). These items represented pain experiences that were commonly listed in pain diaries from previous studies (5) and provided a range of experiences varying from mild tissue damage (eg, sliver) to severe tissue damage (eg, serious accident/injury). The questionnaire was then pilot tested in a sample of 35 children from the community who were similar in age to the target population. Minor modifications were made to the questionnaire based on the results of the pilot study. Questions from the original study on recurrent pain, long-lasting pain (chronic) and a child's worst pain experience were retained. Four questions from the Health Behaviour in School-Aged Children study (6) relating to exercise frequency, feelings about school, self-rated health and psychological factors were also included in the questionnaire (6). For the purpose of the present paper, these questions were analyzed to assess for representativeness of the study sample, by comparing responses to a national randomly selected sample of school children.

Children completed the Pain Experience Interview - Short Form in their classroom (211 of 495) or at home (284 of 495). For any pains experienced over the past month, children rated the intensity, affect and duration (Table 2). Pain intensity was rated with a five-point verbal scale: 1 = 'a little bit/slight', 2 = 'a little/mild', 3 = 'medium/moderate', 4 = 'a lot/strong' and 5 = 'a real lot/intense' (7). Pain affect was rated using the facial affective scale, where children chose one of nine faces ranging in emotional distress to match how they felt during the pain experience (8). The faces were coded on an interval scale from 0.04 to 0.97 , derived from previous research on children's numeric ratings of the subjective distress depicted by each face (9). Pain duration was rated with a six-point verbal scale asking children how long the item hurt: 'seconds', 'minutes', 'hours', 'days', 'weeks' and 'do not know'.

\section{Chronic pain classifications}

Questions referring to long-lasting pain were coded and divided into five different categories. The proportion of children identified as 'definite cases' and those identified as 'possible cases' were 
TABLE 1

One-month and lifetime prevalence of the source of self-reported pain in nine- to 13-year-old school children (n=495) according to sex

\begin{tabular}{|c|c|c|c|c|c|c|}
\hline \multirow[b]{3}{*}{ Pain item } & \multicolumn{3}{|c|}{ One-month prevalence } & \multicolumn{3}{|c|}{ Lifetime prevalence } \\
\hline & Boys $(n=232)$ & Girls (n=261) & Total $(n=495)$ & Boys $(n=232)$ & Girls (n=261) & Total $(n=495)$ \\
\hline & \multicolumn{6}{|c|}{ Prevalence (SE) } \\
\hline Headache & $75.0(3.3)$ & $79.7(2.8)$ & $77.5(2.1)$ & $96.6(1.2)$ & $98.5(0.7)$ & $97.6(0.7)$ \\
\hline Sore muscles & $72.4(3.4)$ & $74.3(3.1)$ & $73.4(2.3)$ & $90.9(2.0)$ & $90.8(1.9)$ & $90.9(1.4)$ \\
\hline Sliver & $49.6(4.7)$ & $39.8(4.8)^{\star}$ & $44.4(3.4)$ & $97.4(1.1)$ & $97.3(1.0)$ & $97.4(0.7)$ \\
\hline Earache & $18.1(5.9)$ & $28.4(5.2)^{\star}$ & $23.5(3.9)$ & $79.3(3.0)$ & $84.3(2.5)$ & $81.9(1.9)$ \\
\hline Toothache & $38.3(5.2)$ & $50.2(4.4)^{\star}$ & $44.6(3.4)$ & $81.9(2.8)$ & $81.6(2.7)$ & $81.7(1.9)$ \\
\hline Bee sting & $7.8(6.3)$ & $10.3(5.8)$ & $9.1(4.3)$ & $85.8(2.5)$ & $75.1(3.1)^{\star}$ & $80.1(2.0)$ \\
\hline Injection & $10.8(6.2)$ & $11.1(5.8)$ & $11.0(4.3)$ & $91.8(1.9)$ & $89.3(2.0)$ & $90.5(1.4)$ \\
\hline Stitches & $2.2(6.6)$ & $1.9(6.1)$ & $2.0(4.4)$ & $34.9(5.3)$ & $22.2(5.5)^{\star}$ & $28.2(3.8)$ \\
\hline Menstrual cramps & - & $19.2(5.6)$ & $19.2(5.6)$ & - & $26.4(5.3)$ & $26.4(5.3)$ \\
\hline Broken bone & $1.7(6.5)$ & $5.4(6.0)$ & $3.7(4.4)$ & $22.0(5.8)$ & $24.5(5.4)$ & $23.3(3.9)$ \\
\hline Burn & $30.6(5.5)$ & $41.4(4.7)^{\star}$ & $36.3(3.6)$ & $88.8(2.2)$ & $90.0(2.0)$ & $89.5(1.5)$ \\
\hline Serious accident/injury & $8.2(6.3)$ & $10.3(5.8)$ & $9.3(4.3)$ & $59.1(4.2)$ & $48.3(4.5)^{\star}$ & $53.3(3.1)$ \\
\hline Overnight in hospital & $3.0(6.4)$ & $2.3(6.1)$ & $2.6(4.4)$ & $27.6(5.6)$ & $23.0(5.4)$ & $25.2(3.9)$ \\
\hline
\end{tabular}

*Significant difference with regard to sex; $P<0.05$

TABLE 2

One-month prevalence of self-reported pain in nine- to 13-year-old school children described by intensity, affect and duration, and classified by source of pain

\begin{tabular}{|c|c|c|c|c|c|c|}
\hline \multirow[b]{3}{*}{ Pain item } & & & \multirow{3}{*}{$\begin{array}{c}\text { Pain affect (FAS) } \\
\text { Mean } \pm \text { SD }\end{array}$} & \multicolumn{3}{|c|}{ Pain duration } \\
\hline & \multicolumn{2}{|l|}{ Pain intensity } & & Hours & Days & Weeks \\
\hline & hildren experiencing item, n & Mean \pm SD & & \multicolumn{3}{|c|}{ n (\%) of total responses } \\
\hline Headache & 382 & $2.7 \pm 1.1$ & $0.68 \pm 0.16$ & $242(63)$ & $28(12)$ & $5(1.3)$ \\
\hline Sore muscles & 362 & $2.6 \pm 1.1$ & $0.65 \pm 0.17$ & $249(69)$ & $152(42)$ & $28(7.7)$ \\
\hline Toothache & 220 & $2.5 \pm 1.2$ & $0.67 \pm 0.17$ & $122(55)$ & $68(31)$ & $16(7.3)$ \\
\hline Sliver & 219 & $1.7 \pm 1.0$ & $0.59 \pm 0.17$ & $31(14)$ & $16(7.3)$ & $4(1.8)$ \\
\hline Burn & 179 & $2.7 \pm 1.3$ & $0.70 \pm 0.16$ & $66(37)$ & $31(17)$ & $5(2.8)$ \\
\hline Earache & 116 & $2.9 \pm 1.2$ & $0.71 \pm 0.16$ & $77(66)$ & $37(32)$ & $6(5.2)$ \\
\hline Injection & 54 & $2.1 \pm 1.4$ & $0.58 \pm 0.25$ & $11(20)$ & $8(15)$ & $3(5.6)$ \\
\hline Menstrual cramps* & 50 & $2.8 \pm 1.3$ & $0.70 \pm 0.19$ & $28(56)$ & $9(18)$ & $1(2.0)$ \\
\hline Serious accident/injury & 46 & $4.0 \pm 1.1$ & $0.86 \pm 0.10$ & $39(85)$ & $29(63)$ & $12(26)$ \\
\hline Bee sting & 45 & $2.9 \pm 1.3$ & $0.71 \pm 0.20$ & $15(33)$ & $15(33)$ & $2(4.4)$ \\
\hline Broken bone & 19 & $3.1 \pm 1.9$ & $0.82 \pm 0.14$ & $12(66)$ & $10(56)$ & $4(22)$ \\
\hline Stitches & 10 & $3.1 \pm 1.9$ & $0.66 \pm 0.27$ & $5(50)$ & $3(30)$ & $2(20)$ \\
\hline
\end{tabular}

*Only answered by girls. FAS Facial affective scale

computed because in an epidemiological screening survey both types would receive follow-up examination (4). Definite current chronic pain was defined as children reporting current pain with a duration of a few months or greater. Probable past chronic pain was defined as children having pain that lasted for at least a few months but were not experiencing pain at the time of questionnaire completion. Possible chronic pain was defined as children reporting current pain that had been ongoing for weeks. Possible recurrent pain was defined as children reporting pain (past or present) that lasted less than a few weeks, and not chronic pain was defined as pain that lasted less than a few weeks and was not present at the time of questionnaire completion or over the past month.

Statistical analysis

Using SAS (SAS Institute Inc, USA) version 8 for Microsoft Windows (Microsoft Canada Co), the lifetime and point (one-month) prevalence estimates of pain and associated standard errors were calculated, and the mean and median frequency of acute pains that were commonly reported were determined. Variations were compared by sex using contingency table analyses. Both pain intensity and affect were expressed as means with standard deviations, and pain durations were expressed as raw frequencies and percentages. These data were used to characterize the types of pain experienced by children. The significance level was set at $\mathrm{P}<0.05$ for all statistical tests.

\section{RESULTS}

A total of 1199 consent forms were sent out and 534 were returned, yielding a consent return rate of $45 \%$ (Figure 1). Of the 534 returned consent forms, 495 children agreed to participate in the present study (93\%). Demographic characteristics of the study group are described in Table 3. Fifty-three per cent of the study participants were girls. The majority of respondents 


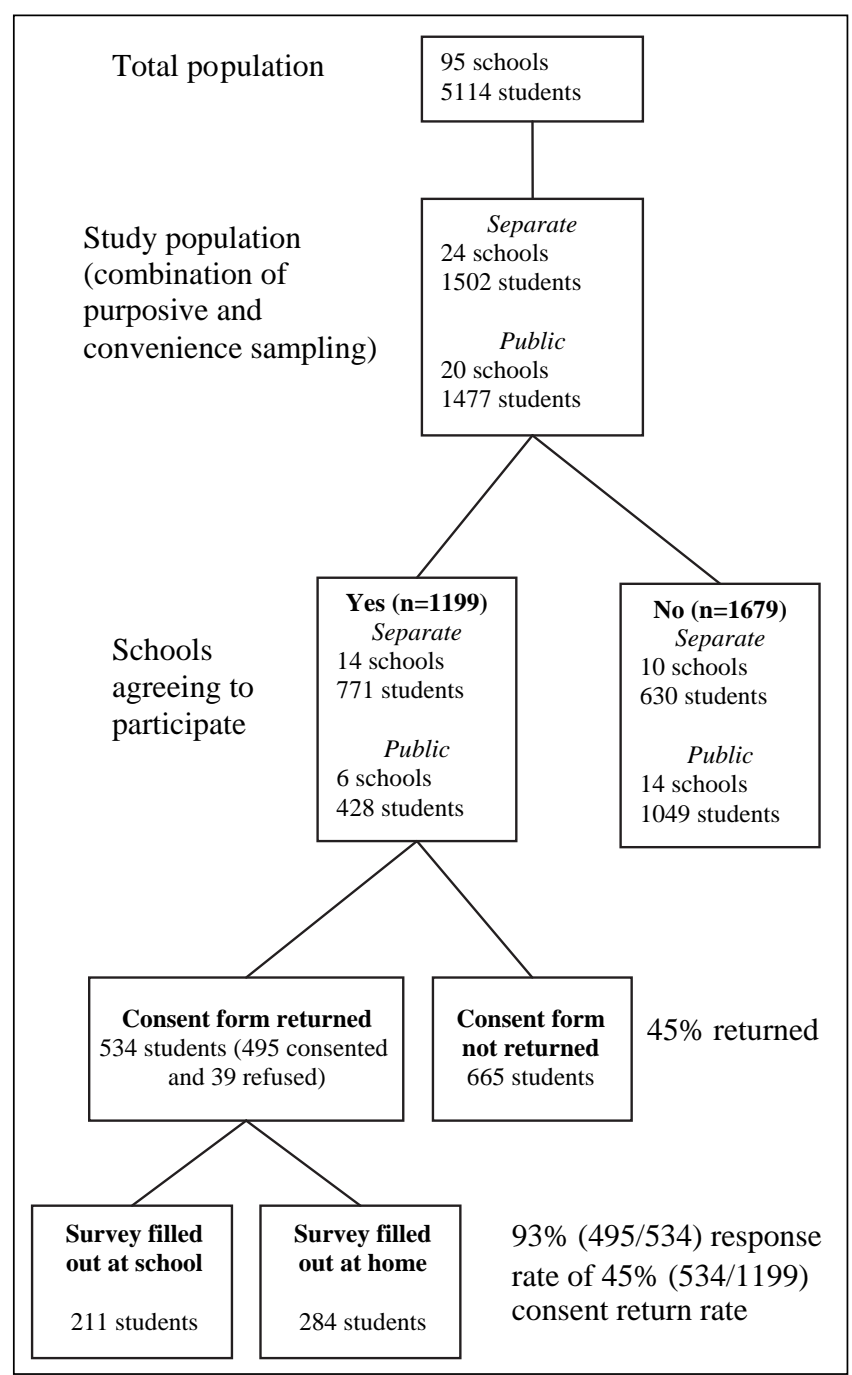

Figure 1) Participant flow chart through recruitment

were $10(37 \%)$ or $11(44 \%)$ years of age. Children from urban schools comprised $71 \%$ of the sample. Almost all children (93\%) answered every question appropriately. The vast majority of children required no assistance (evident by the lack of questions asked of the researcher when present) and completed the survey within $20 \mathrm{~min}$ (shown from children completing in classroom because the time to complete was not available for questionnaires filled out at home).

\section{Acute pain}

Lifetime prevalence: All of the children in the study experienced at least one of the pain items from the Pain Experience Interview - Short Form in their lifetime. The mean number of acute pain items experienced over a lifetime was 8.5 per child of the 13 items in the questionnaire. The proportions of lifetime experienced items ranged from 483 (98\%) children reporting headache to 116 (23\%) children reporting broken bones (Table 1). Headache (98\%), sliver (97\%) and sore muscles $(91 \%)$ had the highest lifetime prevalence values.

Period prevalence: The majority of the 495 children in the study (96\%) experienced at least one of the 13 acute pains listed during the previous month. The mean number of acute items experienced in the last month was 3.5 per child. The
TABLE 3

Demographic and health-related characteristics of nine- to 13 -year-old school children in the study sample $(n=495)$

\begin{tabular}{|c|c|c|}
\hline Variable & $\mathbf{n}$ & $\%$ \\
\hline \multicolumn{3}{|l|}{ Sex } \\
\hline Girls & 261 & 53 \\
\hline Boys & 232 & 47 \\
\hline \multicolumn{3}{|l|}{ Age, years } \\
\hline 9 & 12 & 2.4 \\
\hline 10 & 182 & 37 \\
\hline 11 & 219 & 44 \\
\hline 12 & 77 & 16 \\
\hline 13 & 4 & 0.8 \\
\hline \multicolumn{3}{|l|}{ School } \\
\hline Urban & 351 & 71 \\
\hline Rural & 144 & 29 \\
\hline \multicolumn{3}{|l|}{ Self-rated health } \\
\hline Excellent & 194 & 39 \\
\hline Good & 250 & 51 \\
\hline Fair & 34 & 7 \\
\hline Poor & 4 & 0.8 \\
\hline \multicolumn{3}{|l|}{ School satisfaction } \\
\hline Like it a lot & 158 & 32 \\
\hline Like it a bit & 205 & 41 \\
\hline Dislike it a bit & 70 & 14 \\
\hline Dislike it a lot & 50 & 10 \\
\hline \multicolumn{3}{|l|}{ Exercise frequency } \\
\hline At least once a week & 455 & 92 \\
\hline Less then once a week & 28 & 5.7 \\
\hline \multicolumn{3}{|l|}{ Psychosomatic items } \\
\hline Feeling low more than once a week & 82 & 17 \\
\hline Irritable/bad temper more than once a week & 133 & 27 \\
\hline Feeling nervous more than once a week & 100 & 20 \\
\hline Difficulties falling asleep more than once a week & 156 & 32 \\
\hline
\end{tabular}

proportion of respondents experiencing at least one pain item in the previous month ranged from 382 children reporting headache to 10 children reporting stitches (Table 2). Headache $(78 \%)$, sore muscles $(73 \%)$ and toothache $(45 \%)$ were reported most frequently (Table 1 ).

Sex and questionnaire administration differences: As shown in Table 1, the lifetime prevalences of serious accident/injury, stitches and bee stings were significantly higher among boys than girls. The point prevalence for earaches, toothaches and burns were significantly higher among girls than boys. A statistical comparison revealed no consistent differences in children's responses between the two different school boards. However, the prevalence of three pain items was significantly higher in children completing the survey at home compared with school completion (earaches $18 \%$ versus $31 \%$, toothaches $38 \%$ versus $53 \%$ and burns $31 \%$ versus $43 \%$; $\mathrm{P}<0.05$ ).

Pain characteristics

Children's pain ratings for acute pain items corresponded with the general level of presumed tissue damage usually associated with that type of trauma/disease. As shown in Table 2, mean pain ratings for sliver and injections were 1.7 and 2.1, respectively, rated as 0.59 and 0.58 in affect and lasting a shorter 
TABLE 4

Mean number of episodes of pain condition over the past month by source of self-reported pain in nine- to 13-yearold school children

\begin{tabular}{lrrrc}
\hline & & \multicolumn{3}{c}{ Episodes, mean \pm SD } \\
\cline { 3 - 5 } Pain item & $\mathbf{n}$ & Boys & Girls & Total \\
\hline Headache & 368 & $3.3 \pm 3.8$ & $3.6 \pm 3.6$ & $3.5 \pm 3.7$ \\
Sore muscles & 358 & $3.6 \pm 4.0$ & $3.0 \pm 2.8$ & $3.2 \pm 3.4$ \\
Toothache & 220 & $2.6 \pm 3.7$ & $1.8 \pm 1.5$ & $2.1 \pm 2.6$ \\
Sliver & 219 & $1.9 \pm 2.0$ & $1.8 \pm 1.4$ & $1.9 \pm 1.7$ \\
Burn & 174 & $2.0 \pm 2.2$ & $1.6 \pm 1.3$ & $1.8 \pm 1.7$ \\
Earache & 116 & $1.4 \pm 0.9$ & $1.8 \pm 1.2$ & $1.6 \pm 1.3$ \\
Injection & 52 & $1.3 \pm 0.6$ & $1.6 \pm 2.5$ & $1.4 \pm 1.9$ \\
Menstrual cramps ${ }^{*}$ & 50 & - & $2.9 \pm 3.8$ & $2.9 \pm 3.8$ \\
Serious accident/injury & 47 & $1.7 \pm 1.1$ & $1.5 \pm 1.4$ & $1.6 \pm 1.3$ \\
Bee sting & 46 & $1.2 \pm 0.5$ & $1.1 \pm 0.3$ & $1.1 \pm 0.4$ \\
Broken bone & 19 & $1.3 \pm 0.5$ & $1.1 \pm 0.3$ & $1.1 \pm 0.3$ \\
Stitches & 9 & $1.2 \pm 0.4$ & $1.3 \pm 0.5$ & $1.2 \pm 0.4$ \\
Overnight stay in hospital & 13 & $1.1 \pm 0.4$ & $1.0 \pm 0.0$ & $1.1 \pm 0.3$ \\
\hline
\end{tabular}

*Only answered by girls

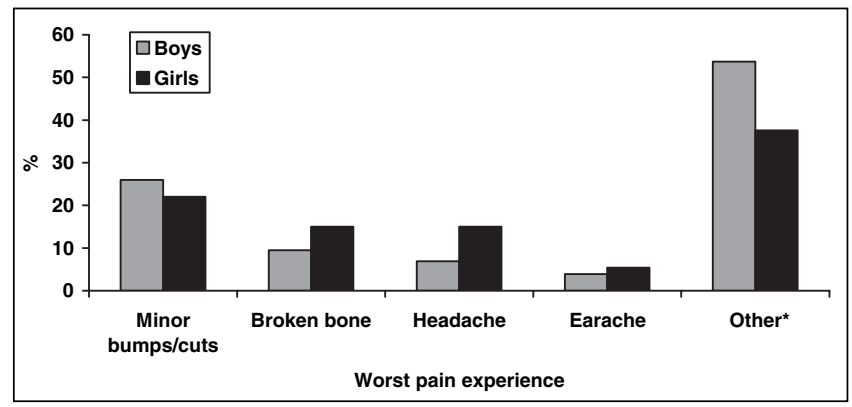

Figure 2) Worst pain experiences reported by school children from Pain Experience Interview - Short Form $(n=495)$. *A wide variety of pain experiences

time. In contrast, children's pain ratings for a broken bone, serious accident/injury and stitches were 3.1, 4.0 and 3.1 respectively, with higher pain, affect and longer duration (Table 2). Headache (mean number of episodes $=3.5$ ), sore muscles (mean number of episodes $=3.2$ ) and toothache (mean number of episodes $=2.1$ ) were the most commonly occurring pains experienced over the previous month (Table 4). Figure 2 shows the most commonly listed pain experiences that children indicated as their worst pain experience ever. Minor bumps and cuts were the most common answer.

Recurrent and chronic pain

Fifty-seven per cent (282 of 495) of children indicated that they had experienced some recurring pain, most commonly headaches, stomach pains and growing pains. Twenty-nine per cent ( 83 of 282) indicated that they had experienced two or more recurrent pain items (Table 5). Forty-six per cent (227 of 495) of children indicated that they had experienced some long-lasting pain. Six per cent (31 of 495) of children were classified as a definite, possible or probable chronic pain condition. Of these children, 11 of $227(4.8 \%)$ reported chronic pain at the time of the questionnaire completion, 11 of 227 (4.8\%) reported a possible chronic pain condition at that time, and nine of 227 (4.0\%) may have had chronic pain in the past (Figure 3). Pain problems included long-lasting illnesses,
TABLE 5

Recurrent pains described by nine- to 13-year-old school children from Pain Experience Interview - Short Form

\begin{tabular}{lcccc}
\hline & $\begin{array}{c}\text { Boys (n=125) } \\
\text { reporting } \\
\text { recurring } \\
\text { pain } \\
\mathbf{n}(\%)\end{array}$ & $\begin{array}{c}\text { Girls }(\mathbf{n}=157) \\
\text { reporting } \\
\text { recurring } \\
\text { pain } \\
\mathbf{n}(\%)\end{array}$ & $\begin{array}{c}\text { Total }(\mathbf{n = 2 8 2}) \\
\text { reporting } \\
\text { recurring } \\
\text { pain } \\
\mathbf{n}(\%)\end{array}$ & $\begin{array}{c}\text { Per cent } \\
\text { of total } \\
\text { study } \\
\text { population } \\
\text { (n=495) }\end{array}$ \\
\hline Number of pains items reported by children & $109(69)$ & $199(70)$ & 40 \\
1 & $90(72)$ & $24(15)$ & $44(16)$ & 9 \\
2 & $20(16)$ & $19(12)$ & $34(12)$ & 7 \\
3 & $15(12)$ & $5(3)$ & $5(2)$ & 1 \\
4 & $0(0)$ & $92(59)$ & $156(55)$ & 32 \\
Leading forms of recurrent pains identified & $58(37)$ & $105(37)$ & 21 \\
Headaches & $64(51)$ & $58(37)$ & $94(33)$ & 19 \\
Growing pains & $47(38)$ & $6(4)$ & $13(5)$ & 2 \\
Stomach pains & $36(29)$ & $19(12)$ & $41(15)$ & 8 \\
Muscle aches & $7(6)$ & $22(18)$ & &
\end{tabular}

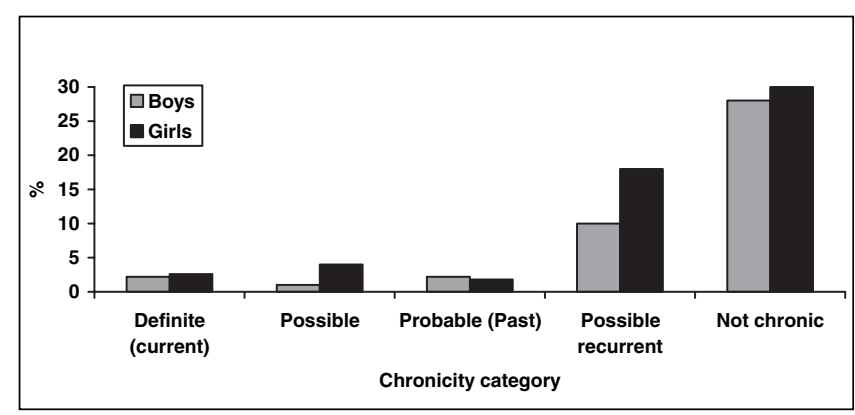

Figure 3) Really long-lasting pain reported by school children using the Pain Experience Interview - Short Form $(n=227)$

broken bones, stomach pains and back pains. Sixty-four (28\%) children reporting long-lasting pain probably have a recurrent pain condition. Almost one-half ( 30 of 64 ) of this group also reported the presence of recurrent pain.

\section{DISCUSSION}

The present study is one of the first epidemiological investigations in North American children to report on the lifetime and point prevalence for acute, recurrent and chronic pain and to rate the intensity, affect and duration of their pain experiences. Few children had difficulty completing the self-administered Pain Experience Interview - Short Form, indicating that the level of comprehension and the method of administration were appropriate for children. The survey methodology, with children independently completing it at school or home, provides a feasible administration technique for use in obtaining population-based estimates on childhood pain and conducting efficient longitudinal studies to identify risk and prognostic factors.

Our study provided an indication of the prevalence and characteristics of certain pain experiences in preadolescent children. Children's self-reports of their acute pains were consistent with what we know about the nature of acute pain. Relatively brief, mild to moderately strong, injury-related pains are the most common pains children experience $(10,11)$. Acute pains were common among children nine to 13 years of 
age, with many children reporting several painful experiences over the past month. Children rated many pains as relatively brief in duration and mild to moderately strong, consistent with our understanding of acute pain caused by routine childhood experiences and consistent with the ratings obtained in the validation study for the Pain Experience Interview (4). Children rated a few types of acute pain, usually associated with more prolonged or severe tissue damage (eg, broken bones and serious accident/injury) as longer lasting or stronger than other types.

Comparison of pain experiences showed that sex differences depended on the specific pain type rather than representing a consistent pattern of differences in prevalence or pain characteristics. For example, boys reported higher lifetime rates of pain related to stitches and serious accidents than girls, consistent with a higher proportion of boys engaging in more rigorous, potentially more risky, physical activities.

Epidemiological data on childhood headache have been well established. Prevalence varies depending on the age and sex of the study population, diagnostic criteria and country of origin. However, headache prevalence for nine- to 13-year-old children (as in our study) varies from $5 \%$ to $11 \%$ for migraine headache and from $27 \%$ to $97 \%$ for acute headache (12). The $98 \%$ lifetime prevalence of headache obtained in our study is consistent with the upper range of estimates reported in European populations, where the prevalence in seven- to 17 -year-olds ranged from $15 \%$ to $97 \%(13-18)$.

Although the formal validation of the Pain Experience Interview - Short Form for diagnosing children with recurrent or chronic pain syndromes was not within the scope of the present study, we used questions that were demonstrated in the original study to have high specificity. Prevalence of recurrent pains such as headaches, stomach aches, growing pains and chest pain range widely from $4 \%$ to $37 \%$ (19). This is comparable to our estimates of $32 \%$ for headaches, $21 \%$ for growing pains and $19 \%$ for stomach aches (Table 5). The consistency between our findings and the literature suggest the Pain Experience Interview - Short Form is a reliable survey for estimating recurrent pain in children.

Like adults, children can experience chronic pain due to injury, trauma, disease, emotional distress and pain of unknown etiology. Yet, we lack definite data on the incidence and prevalence of most types of chronic pain in children. Six per cent of children reported a probable or possible chronic pain condition in our study. In a Dutch study (19) of 5424 school children, one-quarter reported recurrent or continuous pain for over three months. Data on pain severity and persistence is crucial for accurate chronic pain estimates in children, most of the current studies focus on nonspecific pain and on recurrent pains (20).

Methodological challenges arose in the present study due to the ethical requirement to obtain consent via a staged process rather than directly approaching children and families. To access children, we had to first approach school boards, individual schools, principals and, finally, gain parental consent. This process resulted in a very low consent return rate, although not necessarily a low refusal rate. Due to the complex consent process, the true refusal rate is unknown; however, virtually all students who returned a consent form agreed to participate in the study. Many European studies $(17,18,21)$ were conducted within the school system without the apparent complex consent process required by our study and their response rates ranged from $74 \%$ to $93 \%$. One method to potentially improve consent form return rates would be to contact parents via direct mailing to ensure that parents received the information package.

Epidemiological studies on the prevalence of pain in children are based on self report $(2,3)$. In spite of the limitations of self report, many studies have shown that children and adolescents are able to reliably report subjective health complaints (22); thus, self report remains the gold standard in the reporting of pain. Children should be able to accurately describe their subjective experiences of salient events (especially pains that vary from the routine every day injuries sustained in childhood activities) and accurately recall the sensory aspects of recent pains. As such, the Pain Experience Interview - Short Form is a useful population screening tool to assist in the identification of children with potential pain problems who can then be followed up for further assessment and diagnosis.

Like any epidemiological study, biases may have resulted in the present study. The over-representation of Catholic schools due to a labour dispute in the public school board, and the combination of home- and school-completed questionnaires, may have biased our results. A few conditions were found to be reported more often when the questionnaire was completed at school versus at home (eg, earache, toothache and burn). However, we believe these differences would have a minimal impact on the overall conclusions, particularly with respect to recurrent and chronic pain. Item nonresponse was slightly higher on home-completed questionnaires, possibly due to the researcher not being present to clarify issues. Despite the use of a convenience sample and the low consent return rate, the present study provides the first description of sensory and affective pain in preadolescent children in Canada and possibly North America. Although the sampling strategy that was used did not lend itself to generalizing the results, observed reports of perceived health, feelings about school and psychological symptoms were similar to national estimates from the 2001/2002 Canadian section of the Health Behaviours in School-Aged Children study (23). We therefore concluded that in terms of external validity, we have a representative sample of preadolescent children from the general population.

This research provides a foundation to examine the etiology and impact of pain in children. The present study is part of a larger project that also explored the impact of pain on activities of daily living and quality of life (manuscript in progress). Future research is focused on using the Pain Experience Interview - Short Form in longitudinal studies to assess the etiology and impact of recurrent and chronic pain in children. The results of prospective studies can then be used to develop intervention strategies aimed at preventing the development of recurrent and chronic pain in children.

In addition to methodological differences cited previously in epidemiological studies, few studies have used the same instrument for routine use in pediatric populations (20). It is therefore recommended that standardized definitions and instruments be created to make comparisons easier. In our review of the literature, no studies were found that used questionnaires that captured all types of pain. These studies used country-specific instruments, while the present study used a comparable questionnaire and diagnostic criteria. Studies on recurrent and chronic pain had no validity information, and while not perfect, the original study using the Pain Experience 
Interview addressed these issues with a priori hypotheses (4). By comparing results of the present study with that of the original Pain Experience Interview validation study, we found that our data were consistent with the results in that clinical setting (4), which evaluated distinct cohorts of children aged five to 16 years with arthritis, cancer, headache, enuresis and a healthy comparison group.

The present study demonstrated that a modified version of the Pain Experience Interview could be used in school-aged children to collect information on the prevalence, intensity, affect and duration of pain. We found that chronic and recurrent pain is present in children in the general population. Further studies are needed to better understand pain in children. Our study provides a foundation for future studies to examine the incidence, etiology and impact of pain in children leading to the development of improved pain prevention, treatment, management and education strategies.

FUNDING: The present study was supported by a new emerging team grant from the Institute of Gender and Health (GHL 63209) Canadian Institutes of Health awarded to Dr Patricia McGrath.

\section{REFERENCES}

1. Schechter N, Berde C, Yaster M. Pain in Infants, Children, and Adolescents, 2nd edn. Philadelphia: Lippincott Williams \& Wilkins, 2003.

2. McGrath PA. Chronic pain in children. In: Crombie IK, Croft PR, Linton SJ, Leresche L, Von Korff M, eds. Epidemiology of Pain. Seattle: IASP Press; 1999:81-100.

3. VanDenKerkhof EG, van Dijk A, McGrath PA. Prevalence of chronic pain disorders in children. Encyclopedic Reference of Pain 2006. (In press)

4. McGrath PA, Speechley KN, Seifert CE, et al. A survey of children's acute, recurrent, and chronic pain: Validation of the pain experience interview. Pain 2000;87:59-73.

5. McGrath PA. Pain in Children: Nature, Assessment, and Treatment. New York: Guilford Press; 1990.

6. Currie C, Samdal O, Boyce W, Smith R, eds. Health Behaviour in School-aged Children: A WHO Cross-national Study (HBSC): Research Protocol for the 2001/2002 Survey. Child and Adolescent Health Research Unit, University of Edinburgh.

7. McGrath PA, Koster AL. Headache measures for children: A practical approach. In: McGrath PA, Hillier LM, eds. The Child with Headache: Diagnosis and Treatment. Seattle: IASP Press; 2001:29-56.

8. McGrath PA, Seifert CE, Speechley KN, Booth JC, Stitt L, Gibson MC. A new analogue scale for assessing children's pain: An initial validation study. Pain 1996;64:435-43.

9. McGrath PA, Speechley KN, Seifert CE, Gorodzinsky FP. A Survey of Children's Pain Experience and Knowledge - Phase 1. Seattle: IASP Press; 1997:903-16.

10. Ross DM, Ross SA. Childhood Pain: Current Issues, Research, and Management. Bethesda, Maryland: National Institute of Child Health and Human Development; 1982.

11. McGrath PA. Pain in Children: Nature, Assessment and Treatment. New York: Guilford; 1990.

12. McGrath PA. Headache in children: The nature of the problem. In: McGrath PA, Hillier LM, eds. The Child with Headache: Diagnosis and Treatment. Seattle: IASP Press;2001:1-27.

13. Al Jumah M, Awada A, Al Azzam S. Headache syndromes amongst schoolchildren in Riyadh, Saudi Arabia. Headache 2002;42:281-6

14. Antoniuk S, Kozak MF, Michelon L, Montemor Netto MR. Prevalence of headache in children of a school from Curitiba, Brazil, comparing data obtained from children and parents. Arq Neuropsiquiatr 1998;56:726-33.

15. Bandell-Hoekstra IE, Abu-Saad HH, Passchier J, Frederiks CM, Feron FJ, Knipschild P. Prevalence and characteristics of headache in Dutch schoolchildren. Eur J Pain 2001;5:145-53.

16. Groholt EK, Stigum H, Nordhagen R, Kohler L. Recurrent pain in children, socio-economic factors and accumulation in families. Eur J Epidemiol 2003;18:965-75.

17. Laurell K, Larsson B, Eeg-Olofsson O. Prevalence of headache in Swedish schoolchildren, with a focus on tension-type headache. Cephalalgia 2004;24:380-8.

18. Smedbraten BK, Natvig B, Rutle O, Bruusgaard D. Self-reported bodily pain in schoolchildren. Scand J Rheumatol 1998;27:273-6.

19. Perquin CW, Hazebroek-Kampschreur AA, Hunfeld JA, et al. Pain in children and adolescents: A common experience. Pain 2000;87:51-8.

20. McGrath PA. Chronic pain in children. In: Crombie IK, Croft PR, Linton SJ, Leresche L, Von Korff M, eds. Epidemiology of Pain. Seattle: IASP Press;1999:81-100.

21. Jones MA, Stratton G, Reilly T, Unnithan VB. A school-based survey of recurrent non-specific low-back pain prevalence and consequences in children. Health Educ Res 2004;19:284-9.

22. Wisniewski JJ, Naglieri JA, Mulick JA. Psychometric properties of a Children's Psychosomatic Symptom Checklist. J Behav Med 1988;11:497-507.

23. Boyce W. Young people in Canada: Their health and well-being. <http://www.phac-aspc.gc.ca/dca-dea/publications/hbsc2004/index_e.html> (Version current at October 20, 2006). 


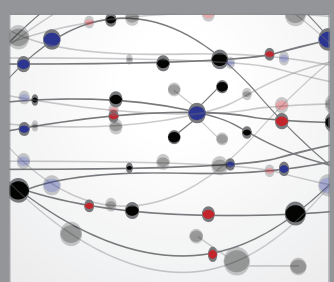

The Scientific World Journal
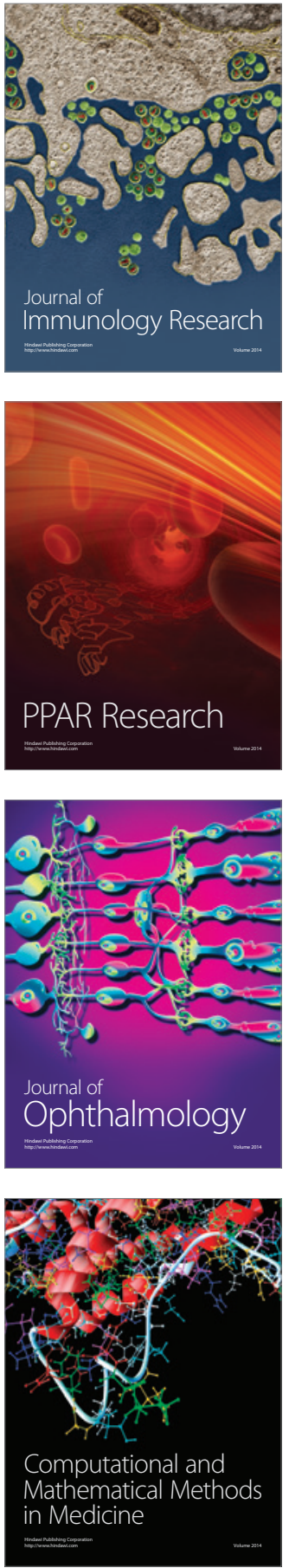

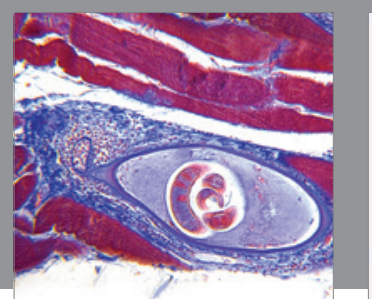

Gastroenterology Research and Practice

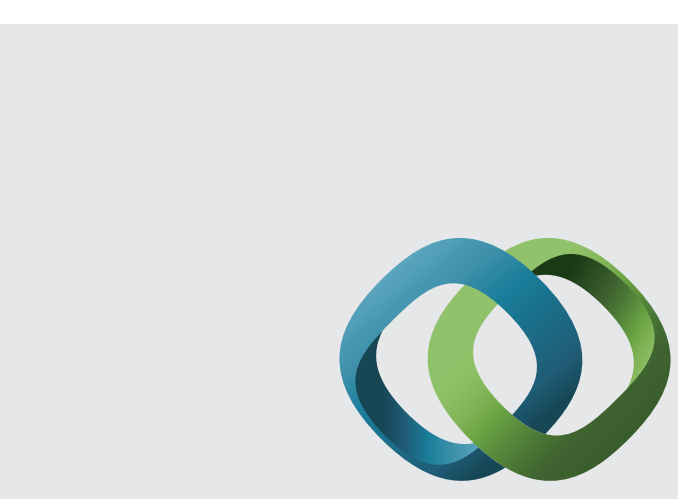

\section{Hindawi}

Submit your manuscripts at

http://www.hindawi.com
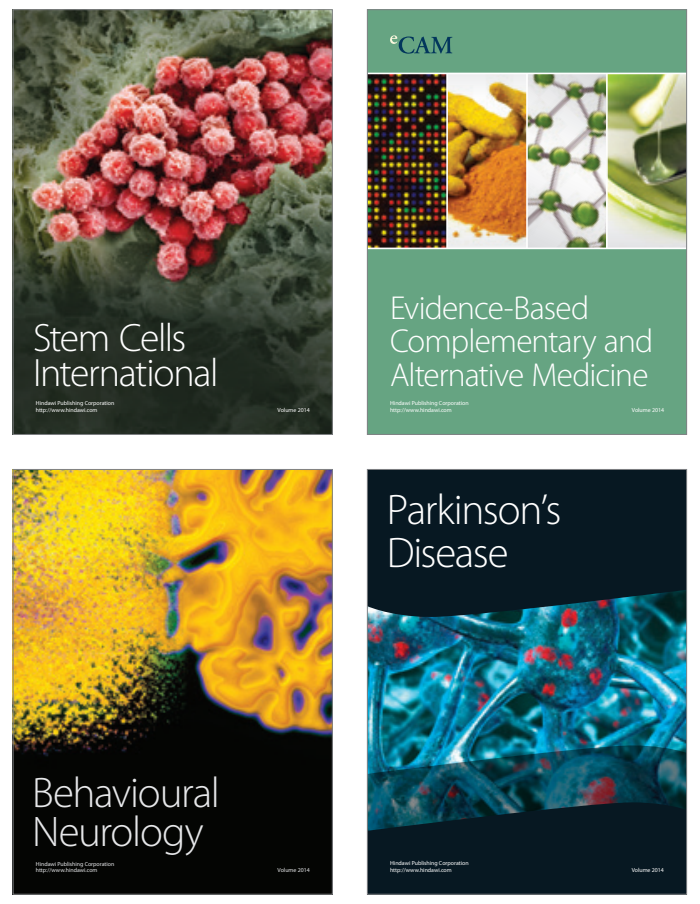
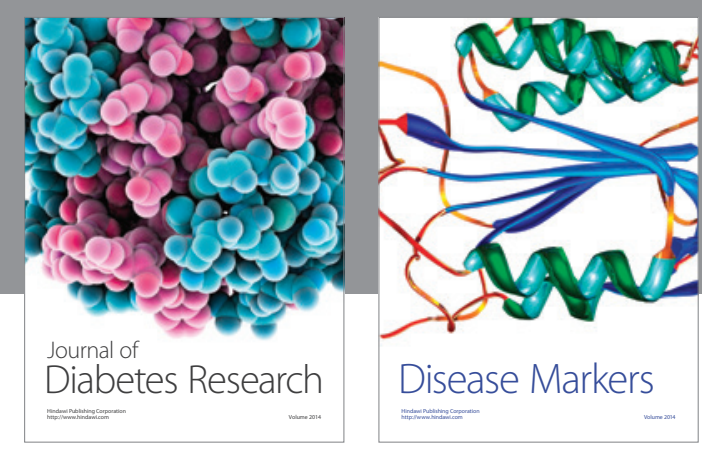

Disease Markers
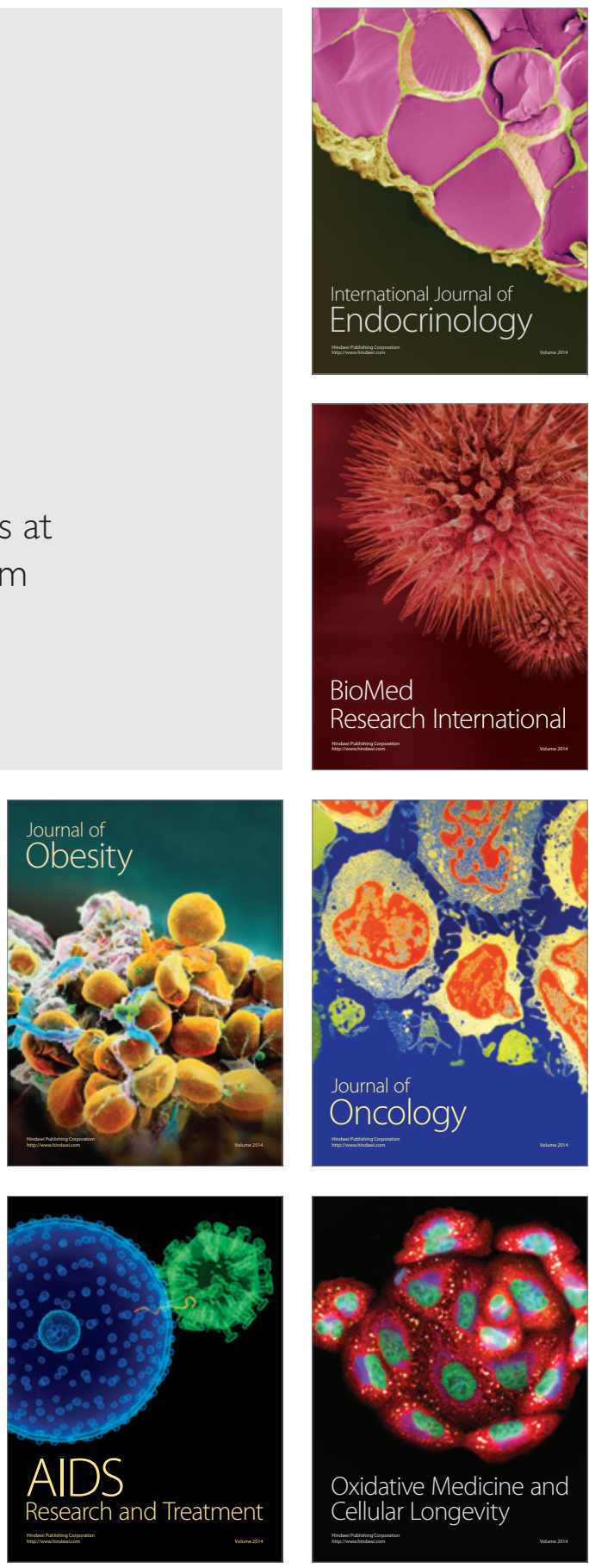